Tugaj, A., Shebek, N., and Dubynka, 0.

Department for Organization and Management of Construction,

Kyiv National University of Civil Engineering and Architecture,

31, Povitroflotsky Ave., Kyiv, 03037, Ukraine,

+380 44245 4851, kaf org@ukr.net

\title{
IDENTIFYING NEW AND STRUCTURING EXISTING ORGANIZATIONAL AND TECHNOLOGICAL APPROACHES TO MANAGING THE ENGINEERING PREPARATION CYCLE FOR CONSTRUCTION \& INVESTMENT PROJECTS
}

Introduction. The development of construction industry in the country, its technological and production components require a careful approach to the organization and management issues of investment construction projects by building advanced models of interaction among construction process stakeholders.

Problem Statement. Almost whole of real estate development is realized within the framework of construction \& investment projects. Inasmuch as these projects are directly related to both the development of residential real estate segment and the technological process of construction works, their structure needs to be divided into the organizational and the production components.

Purpose. To consider the organizational and managerial structure of the construction process at the engineering preparation stage of construction \& investment project in the sphere of residential real estate, to identify the main goals and functions of the project stakeholders.

Materials and Methods. Systematic method for studying the design solutions of residential real estate projects using innovative design and engineering technologies for the development and implementation of construction works cycle.

Results. The analysis of existing residential development projects and new construction projects has shown that the efficiency of construction projects is secured by timely and coordinated decision-making on fundamental issues at each organizational and managerial level even at the stage of engineering preparation of construction project.

Conclusions. Research and ongoing monitoring of real estate construction development have indicated the need to determine an optimal model for the effective implementation of construction \& investment projects through the use of specific tools for financing, managing, organizing, and monitoring the implementation of construction \& investment projects. The structure of this model shall be scientifically justified.

Keywords: construction, real estate, management, and innovative approaches to project cycle organization.

The economic and business reform and development in Ukraine is going hand in hand with the dynamics of construction industry and its components. The status of construction \& investment projects is instable and constantly varying. This is caused by the restructuring of the financial services market and the application of certain

(C) TUGAJ, A., SHEBEK, N., and DUBYNKA, O., 2019 investment instruments both at the international level and in the domestic market of Ukraine.

The emergence and development of construction \& investment projects in Ukraine depend primarily on increasing the competitiveness of the national socio-economic system (subject to the development of innovations) through the adoption of consistent strategic decisions and improvement of organizational and managerial app- 
roaches to the full cycle of the construction project. Innovative construction entrepreneurship in the sphere of residential real estate plays an important role in terms of achieving the mentioned goals.

Organizational and managerial decisions, their efficiency and systemic approach manifest themselves, first of all, in improving the formation of a strategy by contracting organizations and investors; in expanding market share and competitiveness by management corporations; in using advanced technologies by developers; and in raising the efficiency of business processes by all stakeholders of construction project.

Constant changes in the environment and competition among construction companies and developers play a very important role in choosing a structured model for the interoperation of all parties involved in the construction of real estate or a specific comprehensive approach and management tools, which, from the very beginning, should ensure the maximum profitability of the project, the minimum possible and estimated capital investments in the project, and the shortest terms of performance and the handover of completed works.

The combination of economic, licensing, technological, and legal aspects in a single construction \& investment project requires perfect knowledge, skills, and competences, from the preparatory stage to the start of the project, in particular, throughout the site preparation and ongoing monitoring of the whole project cycle, in terms of substantiating the peculiarities and advantages of chosen decision. The qualitative preparation of the project and the establishment of effective interoperation of the parties involved in construction project at the initial stage underlie an innovative model of real estate development management, which becomes a fundamentally new concept for the organization of construction and development activities in the country.

Among those who have made a significant contribution to the study of theoretical and methodological principles of real estate develop- ment, basic principles of organization and management of investment in construction there are A. M. Asaul, O.R. Degtiar, Yu.M. Kovalenko, O.O. Liakhova, S.G. Chigasov, S.N. Maksimov, I.I. Mazur, V.D. Shapiro, Alan Griffith, A. Frey, and J. Friedman. S.A. Ushatskyi, V.O. Pokolenko, O.M. Gladka, O.P. Petrash, and others have studied the development of construction industry in Ukraine. There are many publications on the solution of problems in construction, in particular, the development, organization, and management of housing construction projects, however, the present-day situation in the industry and segments still has to be studied.

The purpose of this research is to analyze the organizational and technological status of real estate projects that have been implemented in terms of the structure of management of the construction \& investment cycle at the stage of site preparation with the main goals and functions of the project stakeholders specified.

In 2005-2010, a large share of investments in Ukraine was accounted for the construction of commercial real estate, office and business centers, shopping malls, entertainment and logistics centers. In 2011 - 2012, there were reported a significant increase in the investments and financing of residential construction in the central parts of oblast cities and a significant recovery and growth in housing construction in the central districts of the city of Kyiv.

The demand-driven development business in Ukraine is growing and is focused on real estate construction \& investment projects that are not limited to a few high-rise buildings. Investors are interested in large housing complexes with a new modern infrastructure. At the same time, there emerges the system of relations between the contracting organization and the designer, on the one hand, and the contractor, on the other hand, depending on the scope and complexity of the future real estate object. From the very beginning of any construction \& investment project, at the stage of site preparation, the questions that has to be answered concern the project stakeholders, 
their functions and overall structure of works for the project implementation.

The concept of "development" in the construction industry means the type of professional business aiming at finding and implementing the best option for the real estate market growth, from the definition of the idea and the creation of a general concept of the project (its visualization) to the completion of turnkey object, its further sale in the real estate market and regular maintenance (operation). The term "development" means growth and becoming more advanced $[1,13]$. Development projects are implemented by raising large investments for a long time.

The concept of "development" has four interrelated meanings. Firstly, development is the qualitative material conversion of immovable property by constructing buildings and structures, which results in growing its value and, as a rule, in increasing the aggregate real estate stock. Secondly, it is a kind of professional business activity related to the organization and implementation of project stages. Thirdly, it is a way to implement real estate projects, which ensures maximum efficiency of the object created and the greatest added value at minimum expenses. Fourthly, development continues the advancement of the object after its construction.

Having analyzed the investment projects, one can note that a significant part of the implementation of construction projects falls on the existing processes of development of buildings and structures or land development/redevelopment. Besides the developer, the investment process of making a civil engineering object involves several independent organizations that have different responsibility and objectives for gaining an economic effect (profit) [2, 193-195]. Below, there is a brief description of the main stakeholders of construction projects.

The investor is a subject of investment activity, which gives financing for the construction of an object at the expense of its own or borrowed funds. It has a title to an absolute disposition of investment results: defines the sector of capital investments, develops terms and conditions of construction works contracts, makes decisions on organizational forms of construction and appoints designers, contractors, suppliers through issuing calls for bids or personal offers, forms financial and credit relations with all stakeholders of the investment process. The investor may be a contracting organization, a borrower, a buyer of construction products (construction object) and act as developer.

The contracting organization is a corporate entity or individual who is responsible for organizing and managing the construction of object at all its stages - from the development of feasibility study to the commissioning of object, using a leased land plot allotted for construction.

The developer is a corporate entity or individual who owns or uses a plot of land and has been duly licensed for construction, reconstruction or demolition of a construction object, in accordance with the procedure established by the applicable legislation of Ukraine.

The contractor (general contractor, subcontractor) is a construction firm (corporation) that performs construction works under works contract. The general contractor is liable to the contracting organization for the compliance of production process with the terms and conditions of the contract, the design, the requirements of construction norms and rules, the specified budget, the quality requirements, and the specified duration of construction works.

The designer (general designer) is a design office or surveying firm that under contract with contracting organization, develops design and budget of the construction object. The general designer is responsible for the quality of the design, the technical and economic indicators of the construction object, the supervision over the contractor's compliance with design solutions (designer's supervision over construction works).

The user is a corporate entity or individual who uses the property as owner or based on a title granted to him by an owner. 
The operating organization is a corporate entity or individual who maintains the object as owner or on behalf of the owner (mostly often, an investor).

The manager is a professional manager, corporate entity or individual who performs administration of the project at all or individual stages of investment cycle.

The project manager performs functions on behalf of the owner who hires it, without interfering in the economic activities of construction project stakeholders.

The supplier is a corporate entity or individual who supplies materials necessary for the construction, which are produced by its own facilities or purchased from other parties.

The research organization is a corporate entity or individual who conducts research works, on initiative of a competent government supervision body or under direct contracts with contracting organizations, designers and contractors [3].

The mentioned list of stakeholders in the construction and investment cycle of construction project implementation outlines its structure that, at further consideration, has a more branched system with financial, organizational, and technological components. Implementing construction \& investment projects, within the framework of idealized powers and functions, is considered to be the most complicated activity in the real estate market, since one project combines construction, realtor, legal, and financial operations, which collectively influence the construction product.

The construction process is characterized by a high level of distribution of social labor, the complexity of construction objects, a large number of options for technology and organization, specialization and cooperation, and other factors. This implies a plenty of options for solving the tasks of site preparation, planning and construction management.

Project management is the use of knowledge, experience, methods and tools for project works to meet the project requirements and expectations of the project stakeholders. In order to meet

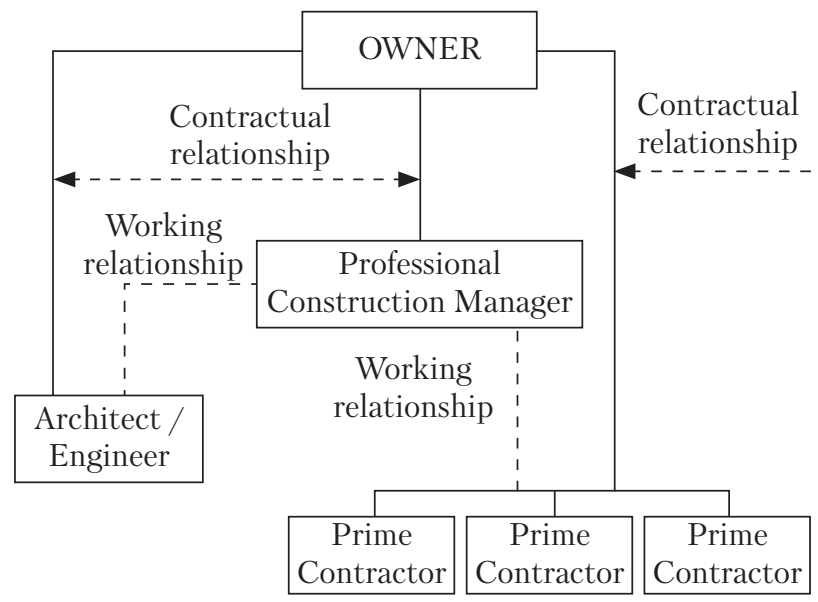

Fig. 1. Construction project management model

these requirements and expectations, it is necessary to find an optimal balance between goals, terms, costs, quality, and other project characteristics [4].

Worldwide practice has shown that project management is a special field of management that has a significant effect. Professionals in this area are in-demand and well-paid, for example, in the United States, project manager is the third toppaid profession behind lawyers and doctors. The project management methodology has become a management standard for thousands organizations and is used almost by all large corporations.

Currently, ANSI project management standards (approved by the American National Standards Institute) are used, and ISO 10006 project management standards [5] have been drafted.

The management of construction \& investment project, in particular, the construction works, significantly speeds up the implementation of efficient technological models of construction, as well as other project documents (flow charts, traffic management schemes, etc.).

The model is a simplified representation of some object in the form convenient for study or analysis. It is a link between theory and reality.

The production process and the construction \& investment process can be presented as an imaginary, schematic, descriptive or graphical model 


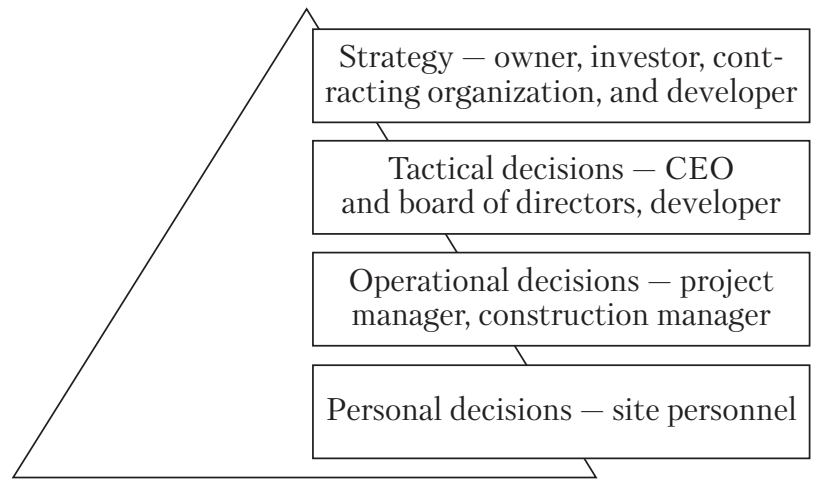

Fig. 2. Structure of decision-making

that helps to plan and to supervise over the works ahead in time. Using the chosen model, it is possible to outline the options for implementing programs and to make a schedule of decision-making for the project $[6,104]$.

The methodological framework for successful construction business is the optimal use of financial, technical, and human resources in the model of construction project (or multi-project) management - Professional Construction Management (PCM) Contract (Fig. 1) [7, 26].

The top level of this structure, the Owner, is represented by the contracting organization, the developer or the investor. The developer works in this system of relations, with the bottom level showing the formal and production relations between the project manager (who acts on behalf of the contracting organization) and the contractors.

The model of interoperation among the stakeholders of construction \& investment project is a primary scheme and shows the conceptual content of decisions taken by all stakeholders in the course of project. At the specified stage, the contracting organization or the investor makes strategic decisions on investing in construction products (objects) for gaining profit from the sale of the finished object, as well as decisions on existing and projected risks. Together with the developer, they manage assets and allocate further investments, thereby creating a favorable climate for their business and the environment.
The next link is Professional Construction Manager. Proceeding from the main objectives, tasks, and requirements established by the contracting organization, the members of this group can make tactical decisions on investments and production process throughout the project implementation. The contracting organization may interfere in the activities of this team only from the point of view of more efficient management, may amend/modify the design and budget documentation based on marketing research in terms of product appeal. The responsible person for the implementation of construction works, the Construction Manager, is authorized and has professional skills in decisionmaking for the implementation of organizational or technological operations. The personal decisions are made by site personnel who is responsible for construction and engineering works. The structure of decision-making is shown in Fig. 2 $[8,20]$.

The site preparation stage as an individual organizational and management system, includes the following activities:

+ developing a concept and format of future development of the real estate object and getting its approval from the contracting organization;

+ Making estimates for the construction object and getting necessary approvals from component government bodies;

+ Adjusting design solutions for the site in terms of identification of structures and utilities to be dismantled, demolished or relocated before commencing works of the zero cycle and obtaining the necessary permits and licenses;

+ Preparing the construction site, installing temporary buildings, structures, and production facilities for the zero cycle of works.

The organization of site preparation management requires an efficient combination of elements, links of the management system and its interoperation with the construction site and other management systems, according to the levels of responsibility. In this aspect, the organization of management provides the following: 


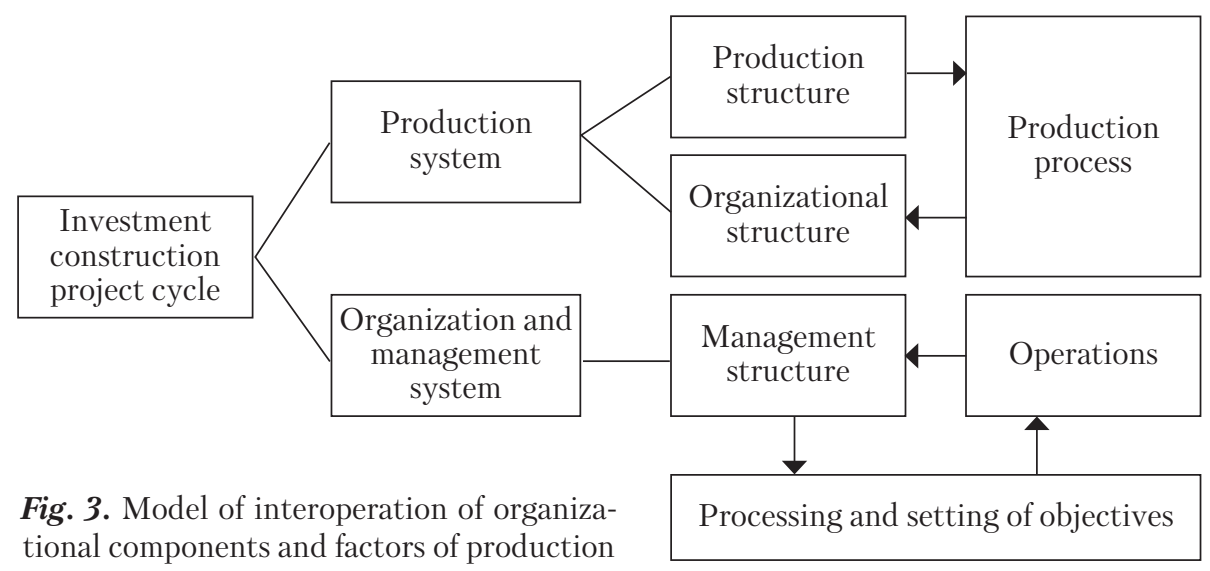

+ creation of the most favorable conditions for implementing the design decisions and achieving the conceptual parameters of construction object;

+ development and implementation of tasks at a specific stage, determination of the duration and flowchart of work equipment translocation in the production process;

+ regular production process, high efficiency of the process, and minimum costs of production resources.

Hence, the organization covers the structure of both the controlled and the controlling subsystems, while ensuring the production of real estate object and influencing the teams of professionals in terms of decision-making and responsibility.

For more effective organization of interoperation among the stakeholders of construction project at the stage of site preparation it is advisable to consider and to apply an interoperation model of organizational components and factors of production environment for the system performance and efficiency of its individual components (Fig. 3).

Organizational structure is an aggregate of individual departments and specialized services, which enables a comprehensive conceptual organization and coordination of functions related to administration, development, and implementation of management decisions to implement the business plan, project documentation, production cycle, and maintenance of construction object.
The production structure with administration elements shows the relationship between the administrative staff, producers of goods or services, and the organization of joint activities of the participants in the production process.

The distribution of administrative and production relations among the stakeholders of construction project and their ranking in terms of the levels of project decisions make it possible to specify the essentials of the ultimate goal at each level.

The main purpose of investors and contracting organization is the construction of civil engineering object with given parameters of investment attractiveness and its handover to operation, with minimizing total costs and reducing construction time in order to ensure the shortest possible payback or property sale period for returning the investments and receiving additional profit as priorities.

Not in every instance, for the reason of saving, the materials and technologies correspond to the declared format of the construction project. In some cases, the investor tries to interfere in economic activity of developer, supplier or general contractor, which drags out the coordination of certain issues and, as a result, extends the period of works or procurement of materials and equipment. In this case, one can observe not only a mechanism of managing the investment and construction cycle on the part of investors and developers, but also a hybrid style of work of manage- 
rial bodies with respect to the functions of developer and contractor.

In practice, the developer may perform not only the functions related to management and development of the project. At the same time, the managing director approves amendments and modifications to the documentation, issues variations to the works or materials, upon the investor's order.

However, it is necessary to place greater focus on the fact no technological process can be immediately interrupted or resumed. A long process of site preparation can combine several types of civil engineering works. Therefore, it is necessary to separate processes or works in the production organization subsystem, which in a shorter period will kick start to the main works, for example, excavating a foundation pit, constructing retaining walls and a foundation of the building. The developer is not interested in forced downtime, since its main task is to get the maximum profit from construction works as soon as possible. To redeem the time, it is necessary to use additional technical, material, and human resources, but this implies additional costs, beyond the contract bill of quantities. In addition, their approval also takes time.

The designer prepares a certain scope of design documentation and cost estimates, but since modifications are required permanently, it feels a lack of resources and time, which has an adverse effect on quality and causes delays in the preparation of documentation. As a result, the contractor receives the revised drawings with delays and the terms of construction works shift.

Consequently, construction \& investment projects bring together many stakeholders, including manufacturers of products, materials, and equipment, suppliers and logistics companies; many construction and assemblage companies and specialized enterprises; all employees and site workers. All of them are components of a mechanism for transforming the idea into the physical product of effective work, i.e. real estate object, and for gaining a financial profit.

In order to more effectively organize the interoperation of stakeholders of construction \& in- vestment projects and the future development of housing construction in Ukraine, it has been proposed to consider and to translate into practice the following organizational and technological approaches and solutions:

+ The investors and contracting organizations should place greater focus on the business plan in order to take into consideration external financial risks and to prevent the stopping or freezing of cash flows, to elaborate the design by approving the format of the object with a detailed description of its main components, and to clearly separate the responsibility and undertakings of the parties to contracts;

+ Currently, the developer, like managing directors of the contracting organization, pays insufficient attention towards marketing and other researches on real estate demand, a qualitative and social component of potential buyers. It should be kept in mind that in order to promote the project, the developer should expand the package of offers, options, and services for the ultimate user of residential space;

+ The managers and contractors should plan the works in such a way as to maximally efficiently use available human and material resources, to reduce the time for preparatory or ongoing work, and to widely apply new technologies and information resources using software systems. The contractor qualification must improve over time and meet the requirements of construction industry;

+ The designers should monitor any changes in the order and execution of design works, timely re-certify and improve qualification of their staff, more flexibly interoperate with the contracting organization and the contractors, and monitor the performance of joint efforts.

The determination of optimal model for effective implementation of construction \& investment projects with the help of certain tools for financing, managing, organizing, and supervising over the performance of works are the main components to be monitored and studied in the sphere of real estate construction based on the principles of development. 


\title{
REFERENCES
}

1. Mazur, I. I., Shapiro, V. D., Olderogge, N. G. (2009). Real Estate Development: directory of the professional. Moscow: Omega-L.

2. Livinsky, O. M., Kurok, O. I., Dudar, I. N., Tonkacheyev, G. M., Bondarenko, M. I., Khomenko, O. G., Savenko, V. I., Rovenchak, T. G., Potapov, T. E., Sharapa, S. P. (2016). Organization, planning and management in construction. Kyiv, UAS, MP Lesya.

3. DBN V.1.2-5: 2007. Edition. Reliability system and security of construction sites. Scientific and technical support of construction objects. Effective 01/01/2008. Kind. officer Kyiv: Minregionbud of Ukraine [in Ukrainian].

4. Starostina, A. O., Kravchenko, V. A. (2004). Risk management: theory and practice. Kyiv: Polytechnic.

5. Nemchin, M., Hobta, V. (2009). Using international standards of risk management in domestic enterprises. Materials of the All-Ukrainian Scientific and Practical Conference of Students and Young Scientists "Modern state and problems of investment development - 2008", Donetsk.

6. Ushatskyy, S., Sheyko, Y., Triger, G. (2007). Construction management. Kyiv: Condor.

7. Fisk, E., Reynolds, W. (2010). Project administration building. New Jersey: Pearson Education, Inc., Prentice Hall.

8. Gladka, O. M. (2012). Milestone strategic decisions in real estate development projects. PhD (Tech). Kyiv [in Ukrainian].

Received 11.10.18

\author{
О.А. Тугай, М.О. Шебек, М.О. Дубинкач \\ Кафедра організації і управління будівництвом \\ Київського національного університету будівництва і архітектури, \\ просп. Повітрофлотський, 31, Київ, 03037, Україна, \\ +380 44245 4851, kaf_org@ukr.net \\ ВИЗНАЧЕННЯ НОВИХ ТА СТРУКТУРУВАННЯ НАЯВНИХ \\ ОРГАНІЗАЦІЙНО-ТЕХНОЛОГІЧНИХ ПІДХОДІВ \\ З УПРАВЛІННЯ ЦИКЛОМ ІНЖЕНЕРНОЇ ПІДГОТОВКИ \\ БУДІВЕЛЬНО-ІНВЕСТИЦІЙНОГО ПРОЕКТУ
}

Вступ. Розвиток будівельної галузі в країні, їі технологічні й виробничі складові вимагають досконалого підходу до організаційних і управлінських питань будівельно-інвестиційних проектів шляхом побудови новітніх моделей взаємодії учасників будівництва.

Проблематика. Інвестиційно-будівельні проекти займають практично весь обсяг девелопменту нерухомості, зазначені проекти безпосередньо пов’язані як з розвитком сегменту житлової нерухомості, так і з технологічним процесом будівельного виробництва, що потребує розподілу на організаційну та виробничу структури.

Мета. Аналіз організаційної та управлінської структури процесу будівельного виробництва на етапі інженерної підготовки будівельно-інвестиційного проекту житлової нерухомості з відображенням основних цілей і функцій учасників проекту.

Матеріали й методи. Системний метод дослідження проектних рішень реалізованих проектів житлової нерухомості з використанням інноваційних технологій проектування, інжинірингу, розвитку та реалізації циклу будівельного виробництва.

Результати. Аналіз впроваджених проектів житлової забудови та нових проектів з реалізації будівельних об’єктів свідчить про те, що ефективність введення в дію будівельних проектів досягається шляхом своєчасного та скоординованого прийняття принципових рішень на кожному організаційному та управлінському рівні ще на етапі інженерної підготовки об’єкту будівництва.

Висновки. Наукові дослідження та поточні спостереження за розвитком будівництва об'єктів нерухомості на засадах девелопменту свідчать про необхідність визначення оптимальної моделі ефективної реалізації інвестиційнобудівельних проектів за допомогою використання певного інструментарію з фінансування, управління, організації та контролю виконання робіт в будівельно-інвестиційних проектах. Структура обраної моделі потребує наукового обгрунтування.

Ключові слова: будівництво, нерухомість, управління, інноваційні підходи організації циклу проекту. 


\section{А.А. Тугай, Н.О. Шебек, А.В. Дубинка \\ Кафедра организации и управления строительством Киевского национального университета строительства и архитектуры, просп. Воздухофлотский, 31, Киев, 03037, Украина, +380442454851, kaf_org@ukr.net \\ ОПРЕДЕЛЕНИЕ НОВЫХ И СТРУКТУРИРОВАНИЕ СУЩЕСТВУЮЩИХ ОРГАНИЗАЦИОННО-ТЕХНОЛОГИЧЕСКИХ ПОДХОДОВ ПО УПРАВЛЕНИЮ ЦИКЛОМ ИНЖЕНЕРНОЙ ПОДГОТОВКИ ИНВЕСТИЦИОННО-СТРОИТЕЛЬНОГО ПРОЕКТА}

Введение. Развитие строительной отрясли в стране, ее технологические и производственные составляющие требуют тщательного подхода к организационным и управленческим вопросам строительно-инвестиционных проектов путем построения новейших моделей взаимодействия участников строительства.

Проблематика. Инвестиционно-строительные проекты занимают практически весь объем девелопмента недвижимости, такого рода проекты непосредственно связаны как с развитием сегмента жилой недвижимости, так и с технологическим процессом строительного производства, что требует распределения на организационную и производственную структуры.

Цель. Рассмотрение организационной и управленческой структуры процесса строительного производства на этапе инженерной подготовки строительно-инвестиционного проекта жилой недвижимости с отображением основных целей и функций участников проекта.

Материалы и методы. Системный метод исследования проектных решений реализованных объектов жилой недвижимости с использованием инновационных технологий проектирования, инжиниринга, развития и реализации цикла строительного производства.

Результаты. Анализ существующих проектов жилой застройки и новых проектов строительных объектов свидетельствует о том, что эфективность запуска строительных проектов достигается путем своевременного и координированного принятия принципиальных решений на каждом организационном и управленческом уровне еще на этапе инженерной подготовки объекта строительства.

Выводы. Научные исследования и текущие наблюдения за развитием строительства объектов недвижимости на основе девелопмента свидетельствуют о необходимости определения оптимальной модели эффективной реализации инвестиционно-строительных проектов посредством использования определенного инструментария по финансированию, управлению, организации и контроля выполнения работ по строительно-инвестиционным проектам. Структура выбранной модели требует научного обоснования.

Ключевые слова: строительство, недвижимость, управление, иновационные подходы организации цикла проекта. 